\title{
An Investigation of the Efficiency of Participatory Budgeting in Achieving Community Development Goals in Port Loko District and City Council
}

\author{
D.E.M. Lavalie ${ }^{1 *}$, S. Subadra ${ }^{2}$ and S. P. Sreekala ${ }^{3}$ \\ ${ }^{1}$ Research Scholar, School of Business Management \\ Department of Business Management, Texila American University \\ 2Department of Commerce, NKR Government Arts College for Women, Namakkal 637001 \\ ${ }^{3}$ Associate Professor, KPR arts and Science College, Coimbatore \\ E-mail: demlavalie@gmail.com; dr.subadraphd@gmail.com; spsreekalaashok@gmail.com \\ *Corresponding author details: Daniel E.M. Lavalie, demlavalie@gmail.com
}

\begin{abstract}
The aim of the study is to determine the efficiency of participatory budgeting in the achievement of community development goals in the Port Loko District and City Council. In the achievement of this goal, a survey questionnaire was administered of which 420 was analysed using simple linear regression and correlational test from the primary data.
\end{abstract}

Keywords: community development; local council; port Loko district and city council; participatory budgeting and efficiency

\section{INTRODUCTION}

Sierra Leone Local council is a sub-national Government created to govern its locality. In the Local Government (ACT, 2004) Section 20 (1), local council is charged with the function of:

A local council shall be the highest political authority in the locality and shall have legislative and executive powers to be exercised in accordance with this Act or any other enactment, and shall be responsible, generally for promoting the development of the locality and the welfare of the people in the locality with the resources at its disposal and with such resources and capacity as it can mobilise from the central government and its agencies, national and international organisations, and the private sector (p.16).

These above responsibilities charged with it created the room for implementation of projects from both government and Non-governmental agencies. Participatory Budgeting (PB) as defined by (LGA, 2020) has been one of the projects implemented by both Port Loko District and City council. But as the councils are operated with a lot of challenges ranging from late disbursement of funds, mobility, bureaucracy, and late implementations of projects, participatory budgeting implemented by these two councils are not exceptions to the above constraints. Therefore the efficiency as defined by (BANTON, 2020) as peak level of performance that uses the least amount of inputs to achieve the highest amount of output, the study wants to determine that level of performance in the participatory budgeting in achieving community development (CD); that is bringing community members to solve problems of their societies (Straza, 2018), has become an issue of concern which needed a study.

\section{OBJECTIVES}

The objectives of the study are:

1) To find out the changes that occurred in the achievement of community development goals due to the changes in efficiency of participatory budgeting in the two councils.

2) To determine the linear relationship between efficiency of participatory budgeting and achievement of community development goals in the Port Loko District and City Council.

\section{METHODOLOGY}

Simple Linear Regression Analysis

Introduction

According to (Bevans, 2020), she said "regression allows you to estimate how a dependent variable changes as the independent variable change and that simple linear regression is used to estimate the relationship between two quantitative variables".

\section{Research Objective}

To find out the changes that occurred in the achievement of community development goals due to the changes in efficiency of participatory budgeting in Port Loko District and City council.

It is worth noting the impact created by efficiency of participatory budgeting in the achievement of community development goals. Hence the study tried to find out the changes that occurred in the achievement of community development goals due to the changes in the efficiency of participatory budgeting in the Port Loko District and City Council. 
The model is as follows:

Starting with the field data collected, the dependent variable (DV) achievement of community development goals and independent variable (IV); efficiency of participatory budgeting is having the formula thus: $A C D G=\beta_{0}+\beta_{1}$ EffictoPB $+\iota_{t}$

Where: $\mathbf{A C D G}=$ Achievement of Community Development Goal

- EffictoPB= Efficiency of Participatory Budgeting - the independent variable (the variable that influences ACDG)

- $\mathbf{B}_{\mathbf{0}}=$ intercept - the predict value of ACDG when EffictoPB is 0

- $\boldsymbol{\beta}_{\mathbf{1}}=$ the regression coefficients- how much we expect ACDG to change as EffictoPB increases.

- $\mathbf{\Psi} \mathbf{t}=$ the error estimate

\section{The study has the following hypothesis:}

- Null hypothesis $\mathbf{H}_{0}=$ The efficiency of participatory budgeting in Port Loko District and City councils are insignificant in the achievement of community development goals.

- Alternate hypothesis $\mathbf{H}_{\mathbf{1}}=$ The efficiency of participatory budgeting in Port Loko District and City councils are significant in the achievement of community development goals.

Having a (0.05) Significant level, at 95\% confidence interval.

\section{Regression Statistics Tables \\ Descriptive Statistics}

The respondents were asked on the efficiency of participatory budgeting in their local councils and wards with the perceptions 1 = strongly agreed, 2 = agreed, $3=$ neutral, $4=$ disagree, and $5=$ strongly disagree. Mean rating was found for each perception.

TABLE 1: Descriptive Statistics

\begin{tabular}{|l|c|c|c|}
\cline { 2 - 4 } \multicolumn{1}{c|}{} & Mean & Std. Deviation & N \\
\hline ACDG & 2.4293 & 1.05596 & 420 \\
\hline EFFICIENCYOPB & 2.1669 & 1.00771 & 420 \\
\hline
\end{tabular}

Source: SPSS 16.0

The Table 1, revealed the descriptive statistic for the effectiveness and efficiency of participatory budgeting in the achievement of community development goals. The efficiency with the mean of 2.17 from the study indicated that the respondents agreed that participatory budgeting is efficient in their local councils and wards.

TABLE 2: Model Summary

\begin{tabular}{|c|c|c|c|c|}
\hline Model & R & R Square & $\begin{array}{c}\text { Adjusted } \\
\text { R Square }\end{array}$ & $\begin{array}{c}\text { Std. Error of } \\
\text { the Estimate }\end{array}$ \\
\hline 1 & $.982^{\mathrm{a}}$ & .964 & .964 & .20053 \\
\hline
\end{tabular}

a. Predictors: (Constant), EFFICIENCYOPB

Source: SPSS 16.0
TABLE 3: ANOVA

\begin{tabular}{|c|l|c|c|c|c|c|}
\hline \multicolumn{2}{|c|}{ Model } & $\begin{array}{c}\text { Sum of } \\
\text { Squares }\end{array}$ & df & $\begin{array}{c}\text { Mean } \\
\text { Square }\end{array}$ & F & Sig. \\
\hline \multirow{4}{*}{1} & Regression & 450.401 & 1 & 450.401 & $1.120 \mathrm{E} 4$ & $.000^{\mathrm{a}}$ \\
\cline { 2 - 8 } & Residual & 16.809 & 418 & .040 & & \\
\cline { 2 - 8 } & Total & 467.210 & 419 & & & \\
\hline
\end{tabular}

a. Predictors: (Constant), EFFICIENCYOPB

b. Dependent Variable: ACDG

Source: SPSS 16.0

TABLE 4: The Coefficients

\begin{tabular}{|c|l|c|c|c|c|c|}
\hline \multicolumn{2}{|c|}{ Model } & \multicolumn{2}{|c|}{$\begin{array}{c}\text { Unstandardized } \\
\text { Coefficients }\end{array}$} & $\begin{array}{c}\text { Standardized } \\
\text { Coefficients }\end{array}$ & \multirow{2}{*}{ t } & \multirow{2}{*}{ Sig. } \\
\cline { 2 - 5 } & B & $\begin{array}{c}\text { Std. } \\
\text { Error }\end{array}$ & \multirow{2}{*}{ Beta } & & \\
\hline \multirow{2}{*}{1} & (Constant) & .200 & .023 & \multirow{2}{*}{.982} & 8.604 & .000 \\
\cline { 2 - 4 } \cline { 3 - 4 } & EFFICIENCYOPB & 1.029 & .010 & & 105.832 & .000 \\
\hline
\end{tabular}

a. Dependent Variable: ACDG

Source: SPSS 16.0

TABLE 5: Summary of Regression Results

\begin{tabular}{|c|c|c|c|c|c|c|}
\hline \multirow{2}{*}{\multicolumn{2}{|c|}{ Model }} & \multicolumn{2}{|c|}{$\begin{array}{l}\text { Unstandardized } \\
\text { Coefficients }\end{array}$} & \multirow{2}{*}{$\begin{array}{c}\begin{array}{c}\text { Standardized } \\
\text { Coefficients }\end{array} \\
\text { Beta }\end{array}$} & \multirow{2}{*}{$\mathbf{t}$} & \multirow{2}{*}{ Sig. } \\
\hline & & B & $\begin{array}{l}\text { Std. } \\
\text { Error }\end{array}$ & & & \\
\hline \multirow[t]{2}{*}{1} & (Constant) & .200 & .023 & & 8.604 & .000 \\
\hline & EFFICIENCYOPB & 1.029 & .010 & .982 & 105.832 & .000 \\
\hline & $\begin{array}{l}\text { R Square } \\
\text { Adjusted R Squ } \\
\text { F } \\
\text { Sig. }\end{array}$ & ire & $\begin{array}{l}.964 \\
.964 \\
1.120 \mathrm{E} \\
.000^{a}\end{array}$ & & & \\
\hline
\end{tabular}

a. Dependent Variable: ACDG

\section{Source: SPSS 16.0}

The decision rule is to reject the null hypothesis and accept the alternative if the sig. value of the variables under study is lower than $(0.05)$ level of significance.

Table 5 above showed the hypothesis tests if efficiency of participatory budgeting in the Port Loko and City council has an impact on the achievement of community development goals. The dependent variable ACDG was regressed on predicting variable EffictoPB to test the hypothesis $\mathrm{H}_{1}$. EffictoPB significantly predicted ACDG, F $(1,418)=1.120 \mathrm{E} 4$, $\mathrm{P}<0.000$, which indicates that EffictoPB can play a significant role in shaping ACDG $(b=1.029, p<0.000)$. These results clearly direct the positive affect of the EffictoPB. Moreover, the $\mathrm{R}^{2}=0.964$ depicts that the model explains $96.4 \%$ of the variance in ACDG, which means we accept the alternate hypothesis and reject the null hypothesis.

\section{Correlation Analysis}

\section{Introduction}

According to (Frost), he said 'a correlation between variables indicates that as one variable changes in value, the other variable tends to change in a specific direction and that Pearson's correlation coefficients measure only linear relationships'. 


\section{Research objective}

The research objective seeks to find out the linear relationship between efficiency of participatory budgeting in the achievement of community development goals in the Port Loko District and City Council. In that respect, the following hypothesis has been framed and tested by performing a Pearson correlation test:

Null hypothesis Ho: The efficiency of participatory budgeting (EffictoPB) has no linear relationship with achievement of community development goals (ACDG) in both Port Loko and City councils.

Alternate hypothesis $\mathbf{H}_{1}$ : The efficiency of participatory budgeting (EffictoPB) has linear relationship with achievement of community development goals (ACDG) in both Port Loko and City councils.

Where: $\mathbf{A C D G}=$ Achievement of Community Development Goal

EffictoPB= Efficiency of Participatory Budgeting

Having a (0.05) Significant level, at 95\% confidence interval.

TABLE 6: Correlations between Achievement of Community Development Goals and that of Efficiency of Participatory Budgeting

\begin{tabular}{|c|l|c|c|}
\cline { 3 - 4 } \multicolumn{2}{|c|}{} & ACDG & EFFICIENCYOPB \\
\hline $\begin{array}{c}\text { Pearson } \\
\text { Correlation }\end{array}$ & ACDG & 1.000 & .982 \\
\cline { 2 - 4 } $\begin{array}{c}\text { Sig. } \\
\text { (1-tailed) }\end{array}$ & EFFICIENCYOPB & .982 & 1.000 \\
\cline { 2 - 4 } & ACDG &. & .000 \\
\hline \multirow{2}{*}{$\mathbf{N}$} & ACFICIENCYOPB & .000 &. \\
\cline { 2 - 4 } & EFFICIENCYOPB & 420 & 420 \\
\hline
\end{tabular}

Source: SPSS 16.0

Table 6 above result revealed that the correlation between efficiency of participatory budgeting and achievement of community development goals, the value showed strong correlation (0.982) and also found to be statically significant going with the $P$-value $(0.000)$.

\section{RESULTS AND DISCUSSIONS}

The results from the study respondents are analysed from the descriptive statistics table (1), regression summary table (5) and the correlation table (6) respectively. From table 1 result, it was revealed by the respondents that the participatory budgeting implemented by Port Loko District and City council were efficient even though with the observed challenges. They also revealed from table 5 the linear regression table an $\mathrm{R}^{2}$ result of $(0.964)$ which reads as $99.4 \%$ changes in the achievement of community development goals is as a result of efficient participatory budgeting practice. Or $99.4 \%$ changes in the dependent variable is a result of the independent variable. Lastly from the correlational test results, it was revealed that, there is a strong correlation between efficiency of participatory budgeting and achievement of community development goals.

\section{CONCLUSION}

The study on the efficiency of participatory budgeting in the Port Loko District and City Council in relation to the achievement of community development goals showed that, participatory budgeting is efficient, had a positive relationship with a strong correlation between them.

\section{REFERENCES}

[1] ACT, L. G. (2004, 03 1). THE LOCAL GOVERNMENT $A C T, 2004$. Retrieved 1101,2020 , from The Local Government Act, 2004-Sierra Leone Web: http://www.sierra-leone.org/Laws/2004-1p.pdf

[2] BANTON, C. (2020, 02 6). Efficiency Definition. Retrieved 11 04, 2020, from Investopedia: https://www.investopedia.com/terms/e/efficiency. asp

[3] Bevans, R. (2020, 02 19). An introduction to simple linear regression. Retrieved 06 08, 2021, from Scribbr:

https://www.scribbr.com/statistics/simple-linearregression/

[4] Frost, J. (n.d.). Interpreting Correlation Coefficients. Retrieved 06 08, 2021, from Statistics By Jim: https://statisticsbyjim.com/basics/correlations/

[5] LGA. (2020). Participatory Budgeting. Retrieved 111 , 2020, from Local Government Association:://www.local.gov.uk/topics/devolution/ engaging-citizens-evolution/approaches-civic-anddemocratic-engagement- 0

[6] Straza, M. (2018, 12 17). COMMUNITY DEVELOPMENT: WHAT IT IS, ITS IMPORTANCE, AND HOW TO CONTRIBUTE IN YOUR CITY. Retrieved 11 1, 2020, from STRAZACULSULTING: https://www.consultstraza.com/communitydevelopment-what-it-is-its-importance-and-how-tocontribute-in-your-city/ 